\title{
Projektově orientovaná výuka v Industry 4.0 - chytrá domácnost
}

\author{
František Koblasa ${ }^{1}$, Radek Votrubec ${ }^{1}$, Ladislav Lelek ${ }^{1}$, Jiří Koudelka ${ }^{1}$ \\ ${ }_{1}$ Technická univerzita v Liberci, Fakulta strojní, Katedra výrobních systémů a automatizace, \\ Studentská 2, 46117 Liberec 1, Česká republika \\ frantisek.koblasa@tul.cz \\ radek.votrubec@tul.cz
}

\begin{abstract}
Anotace: Rozvoj informačních technologií, který vyúst'uje v holistickém pojmu Průmysl 4.0, zvedá požadavky na absolventy, a tím i na instituce poskytující vzdělání. Pouhá inovace kurikula zaváděním nového obsahu učiva bývá nedostačující, a proto mimo rozvíjení technického zázemí a zvyšování kompetencí pedagogů směrem k novým technickým poznáním je vhodná i změna výukového systému. Tento príspěvek se zaměřuje na rozvoj výuky $v$ oblasti chytrých domácností pomocí projektově orientované výuky. Představuje realizaci dvou pilotních studentských projektů, které neobsahovali specifické zadání. V závěru výsledku jsou diskutovány rozdílné prístupy a výsledky řešení spolu s efektivností projektově/problémově orientované výuky.
\end{abstract}

\section{1 Úvod}

Projektově orientovaná výuka je výuková metoda, ve které studenti získávají nejen znalosti, ale také dovednosti tím, že se věnují komplexnímu úkolu, který vyžaduje znalosti z různých oborů [1].

Projektově orientovaná výuka (PBL) má společné znaky s řadou dalších systémů jako je například problémově orientovaná výuka [2]. Pozornost obou je zaměřena na získávání znalostí a dovedností řešením problémů, které vyžadují propojení více znalostních témat, ne pouze jednoho. Hlavním rozdílem mezi nimi je definovaný cíl. V PBL je hlavním cílem dokončit produkt, $\checkmark$ problémově orientované výuce je cílem samotný proces učení [3]. Mezi další principy, se kterými je porovnáváno PBL je experimentální nebo také kolaborativní vzdělávání[4].

Jako hlavním přínosem těchto přístupu je nejčastěji zmiňovaná volnost ve formě učení. Překážky, které studenti zažívají při plánování, projektování a samotné realizaci řešení je zapojují více do řešené problematiky, než klasické pasivní vzdělávání [5]. V prípadě skupinových projektů pak rozvíjejí také sociální dovednosti[6].

Thomas [7] identifikoval pět základních charakteristik PBL:

- Soustředění se na úlohu.

- Otevírání otázek - studenti sami nalézají otázky, které mají vést $\mathrm{k}$ řešení. 
- Kreativní řešení - studenti sami nalézají řešení a tedy nejsou omezovány pouze na řešení již známá.

- Autonomie - studenti si řídí projekt do určité úrovně sami. Pedagogové naplňují roli konzultanta.

- Reálnost - projekt jsou reálné, ne typicky školské a ve většině príipadů obsahují fyzický produkt.

Unikátnost PBL je spatřována právě ve hmatatelných výstupech, které si studenti sami dokumentují (fotografie, videa, náčrtky, výkresy, výpočty), a tím se přirozeně učí o nutnosti systematické dokumentace. Zvláště, když je takový projekt provází delší dobu a je tedy nutné pro úspěšné pokračování uchovat postup v projektu. Navíc díky tomu mohou sami studenti identifikovat své předchozí chyby, které ovlivňují následující postup v projektu.

Studenti tak získávají schopnost samostatnosti a sebereflexe nejenom v tématech odbornosti, ale také při stanovování cílů, plánování, organizace a kooperace. Navíc si sami určují tempo získávání zkušeností a znalostí, protože nemohou přejít na další úroveň bez toho, aby pochopili úroveň předchozí. Tak tomu je v klasických systémech, kde studenti na jakékoli úrovni „doháněji“" znalosti.

PBL má tak svoje uplatnění nejenom v základním a středním školství, ale také ve vyšším vzdělávání [8], [9].

$\checkmark$ na katedře výrobních systémů a automatizace je dlouhá tradice $\checkmark$ projektově a problémově orientované výuce $v$ oblasti zaměřující se zejména na klasické problémy strojního a průmyslového inženýrství [10]. S příchodem nových technologií a principů souhrnně nazývaných Průmysl 4.0 vznikla i nutnost zavést tyto nové poznatky do výuky. Projektově či problémově orientovaná výuka je pro výše zmiňované př́inosy ideální, zejména s ohledem na to, že oblasti jako Internet věcí či chytrá domácnost vyžadují multidisciplinární znalosti.

Pojem chytrý dům, chytrá domácnost, někdy také digitální domácnost, bývá definován mnoha způsoby [11]. Obecně však označuje moderní bydlení vybavené počítačovou a komunikační technikou, která předvídá a reaguje na potřeby obyvatel. Cílem je uživatelům takové domácnosti zvýšit komfort a pohodlí, zaručit co nejvyšší bezpečí a snižit energetické náklady prostřednictvím inteligentní elektroinstalace, jež umožní propojení a řízení jednotlivé techniky $v$ domácnosti. Sjednocením techniky $v$ domácnosti a díky její vzájemné komunikaci získáme jednotné ovládání, které Ize přizpůsobit na míru domu a jeho obyvatelům. Ovládání může být realizováno lokálně ve formě nástěnného systémového dotykového panelu nebo dálkově např́iklad přes internet pomocí chytrého telefonu.

$\checkmark$ následujících kapitolách jsou naznačeny dilemata a výzvy, které studenti řešili v rámci svých projektů chytrých domácností. 


\section{2 Řídicí systémy chytrého domu.}

Prvním rozhodnutím, které museli studenti učinit, je jaký druh řídícího systému uplatní. Řídicí systémy Ize rozdělit podle rozdílné typologie zapojení. Jednotlivé druhy používají odlišné senzory a aktory. Liší se také rozdílnou cenou prvků a spolehlivostí provozu.

\subsection{Centralizované rídicí systémy}

Propojení vstupů (senzorů) a výstupů (aktorů) s centrální řídicí jednotkou je realizováno hvězdicově. To znamená, že každý prvek systému je přímo propojen s centrální jednotkou. Senzory a aktory spolu komunikují jen prostřednictvím této jednotky. Tímto způsobem komunikuje a je zapojené i PLC [12] [13].

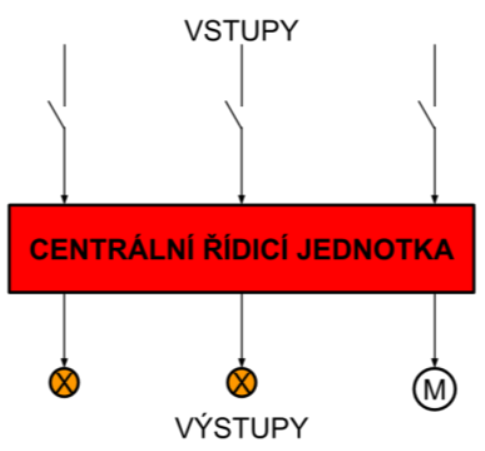

Obrázek 1 - Zapojení vstupů a výstupů na centrální rídicí jednotku [13]

Výhody:

- Vysoká přenosová rychlost informací

- Vyrábí se i levné rídicí systémy

- Levné senzory i aktory [12]

Nevýhody:

- Složitost propojení členů s jednotkou

- Při výpadku jednotky nefunkčnost systému [12]

Jako zástupce centralizovaných systémů Ize uvést například PLC Tecomat Foxtrot (TECO) nebo Siemens SIMATIC S7.

\subsection{Decentralizované rídicí systémy}

U decentralizovaných rídicích systémů jsou všechny jeho vstupy a výstupy připojeny na sběrnici, po které probíhá komunikace mezi členy systému. Nenachází se zde žádná centrální jednotka, každý člen systému disponuje vlastní výpočetní kapacitou [12] [13]. 


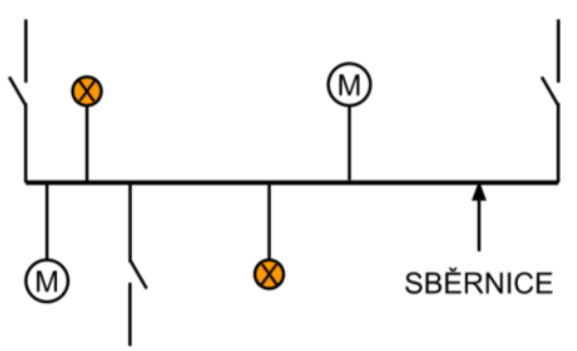

Obrázek 2 - Zapojení vstupů a výstupů při decentralizovaném uspořádání [13] Výhody:

- Jednoduché propojení členů sběrnicí

- Nepotřebuje centrální jednotku

- Nemůže dojít k výpadku celého systému díky decentralizaci [12] Nevýhody:

- Vyšší cena senzorů a aktorů [12]

Kvưli absenci centrální jednotky si všechny periferie decentralizovaného systému zpracovávají a vyhodnocují informace sami. Předávání informace probíhá po sběrnici, a to jakým způsobem je informace předávána, se řídí použitým standardem (protokolem). Nejpoužívanějšími technologiemi přenosu informace jsou LON (Local Operating Network), EIB (European Installation Bus) a standard KNX (Konnex). [14] [15].

\subsection{Hybridní řídicí systémy}

Hybridní neboli částečně decentralizovaný systém je kombinací dvou výše popsaných struktur. $U$ tohoto uspořádání jsou vstupy připojeny na sběrnici, která komunikuje s centrální jednotkou a výstupy jsou zapojeny prímo do rídicí jednotky [12] [13].

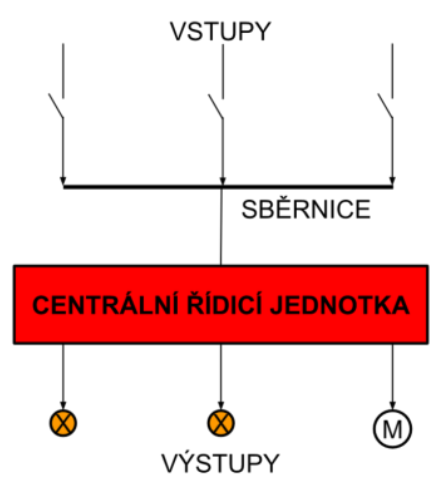

Obrázek 3 - Zapojení vstupů a výstupů při hybridním uspořádání [13] Výhody:

- Jednodušší zapojení vstupů, než u centrálního uspořádání

- Levné periferie 
Nevýhody:

- Potřeba centrální jednotky

- Při výpadku jednotky dojde k výpadku celého systém.

Jako príklady hybridního systému Ize uvést sběrnici Nikobus kombinovanou s centrálními spínacími jednotkami. Systém Nikobus je vyvinut prímo pro domy a byty, proto si vystačí s jednoduchými př́kazy zapnuto/vypnuto. [16]

\subsection{Systémy chytrého domu}

Jelikož je většina systémů inteligentní domácnosti modulární, ve výsledku záleží jen a pouze na studentech, které systémy zvolí.

\subsubsection{Osvětlení}

Osvětlení se nachází v každé domácnosti a jeho propojením se systémem chytrého domu, se jeho používání stává pohodlnějším a příjemnějším. Osvětlení v chytrém domě může obsahovat prvky jako:

- Chytré tlačítko:

- Dálkové ovládání:

- Automaticky řízené světlo:

- Ambientní osvětlení:

- Buzení světlem,

- Dětská pojistka

\subsubsection{Stínění}

Pro příjemné klima v domě je nutné mít okenní stínění. Je jedno, zda jsou na oknech namontovány žaluzie, rolety nebo markýzy. Funkce a prvky, které chytré stínění nabízí jsou např́klad:

- Ovládání tlačítky - stínící techniku instalovanou v domě je možné ovládat jak klasickým, tak i chytrým tlačítkem na zdi.

- Dálkové ovládání - stejně jako světla, tak i stínící techniku Ize ovládat přes mobilní aplikaci nebo aplikaci v počítači.

- Automatické stínění - zatahuje a vytahuje stínící techniku podle denní doby, intenzity světla slunce a podle teploty $v$ domě tak, aby $v$ domě panovalo ideální klima.

\subsubsection{Topení}

Pro topný systém se obvykle využívá elektrický, plynový a automatický kotel na tuhá paliva nebo tepelné čerpadlo. Tyto zdroje tepla Ize kombinovat $s$ krbovou vložkou či krbovými kamny s výměníkem. Systém umožňuji nastavení teploty pro každou místnost zvlášt'. Po nastavení zvolených teplot v 
jednotlivých místnostech udržuje řídící jednotka teplotu na daných teplotách. Při regulaci komunikuje i s ostatními systémy, které se starají o klima v domě. Systém sbírá data o topení pro vyhodnocení efektivity vytápění a ke kontrole vývoje úspor. [13] $\mathrm{V}$ př́padě nutnosti dům upozorní na potřebnou údržbu. Topný systém může být vybaven automatickou diagnostikou nebo funkcí nepřitomnosti, kdy se aktivuje úsporný režim během doby, co je majitel mimo domov. [12]

\subsubsection{Regulace kvality vzduchu a teploty}

Dalším systémem starajícím se o klima a kvalitu vzduchu je ventilace nebo pokročilejší rekuperace. Rekuperace může být dále pasivní (teplým vzduchem, který proudí ven z domu a ohřívá vzduch čerstvý proudící do domu) nebo aktivní (stejná funkce jako pasivní + obsahuje malé tepelné čerpadlo vzduch-vzduch, kterým může dále vzduch ohřivat nebo ho i chladit).

Rekuperace připojená na řídicí jednotku domu, rídí výměnu vzduchu $v$ domě podle čidel kvality ovzduší a vlhkosti, ale díky napojení na jednotku také komunikuje se systémem topení, stínění prípadně klimatizace a do určité míry dokáže regulovat teplotu $v$ domě.

\subsubsection{Bezpečnostní systémy}

Bezpečnostní systém je další součástí chytré domácnosti, která se stará o bezpečí uživatele, ale i domu. Díky integraci bezpečnostního systému do řídicí jednotky je dům pod kontrolou, i když není nikdo doma. Bezpečnostní systém jde jako všechny funkce, chytré domácnosti ovládat vzdáleně. Majitel domu tedy může přes kamery, mikrofony a čidla pohybu sledovat aktivitu $v$ domě přes svůj telefon či PC. Zabezpečení domu může být přes tyto aplikace také ovládáno.

Pomocí pohybových čidel, která jsou již instalována například kvưli osvětlení, je snímán prostor domu a pokud je zaznamenán pohyb a bezpečnostní systém je aktivní, uživatel dostane hlášku o neoprávněném vstupu. Pokud se jedná o planý poplach, je možné ho pomocí mobilního telefonu včas zrušit. Pokud poplach není falešný, dojde k rozblikání domu a spuštění akustické signalizace. Jestliže jsou $v$ domě instalovány kamery, případně i mikrofon, dům zachytí pachatele na video záznam. [14] [15]

Simulací přitomnosti osob dům dokáže předcházet vloupání, když majitelé na delší čas nejsou doma. Simulací je myšleno rozsvěcení světel, pouštění hudby nebo pohyb stínící techniky za neprítomnosti majitelů domu. [1] [14]

Součástí bezpečnostního systému mohou být také čidla na detekci požáru, zaplavení nebo čidla detekující únik plynu. $V$ případě detekce některého $z$ výše uvedených dojde ke kontaktování majitele domu přes mobilní aplikaci a dům učiní potřebné kroky k zažehnání katastrofy (vypne přívod vody, plynu, spustí alarm, kontaktuje bezpečnostní integrovaný systém). [14] 
Dům může předcházet i dalším problémům, jako je zamrznutí trubek, vytopení domu otevřeným oknem při dešti či poškození stínící techniky větrem. [14]

\section{Realizace projektů chytrých domácností}

Tato kapitola popisuje realizaci dvou studentských projektů chytrých domů. Konstrukce jednotlivých domů byla vybrána na základě systémů, které studenti vybrali k realizaci.

Modelový dům č. 1 (Obrázek 4 vlevo) se skládá ze dvou pater (s odnímatelnou podlahou a střechou) a je uzpůsoben pro efektivní řízení proudění $v$ místnostech. Proto má uzavřené venkovní stěny a přistup $\mathrm{k}$ jednotlivým místnostem je možný seshora.

Modelový dům č.2 (Obrázek 4 vpravo) se skládá ze dvou pater, z nichž každé má dvě místnosti. Místnosti jsou od sebe odděleny tenkou dřevěnou stěnou. Model je po obvodu otevřený, a proto je vhodný pro přehledné vedení elektroinstalace.

Oba modelové domy byly pripraveny na instalaci systémů osvětlení, vytápění a bezpečnostního systému.

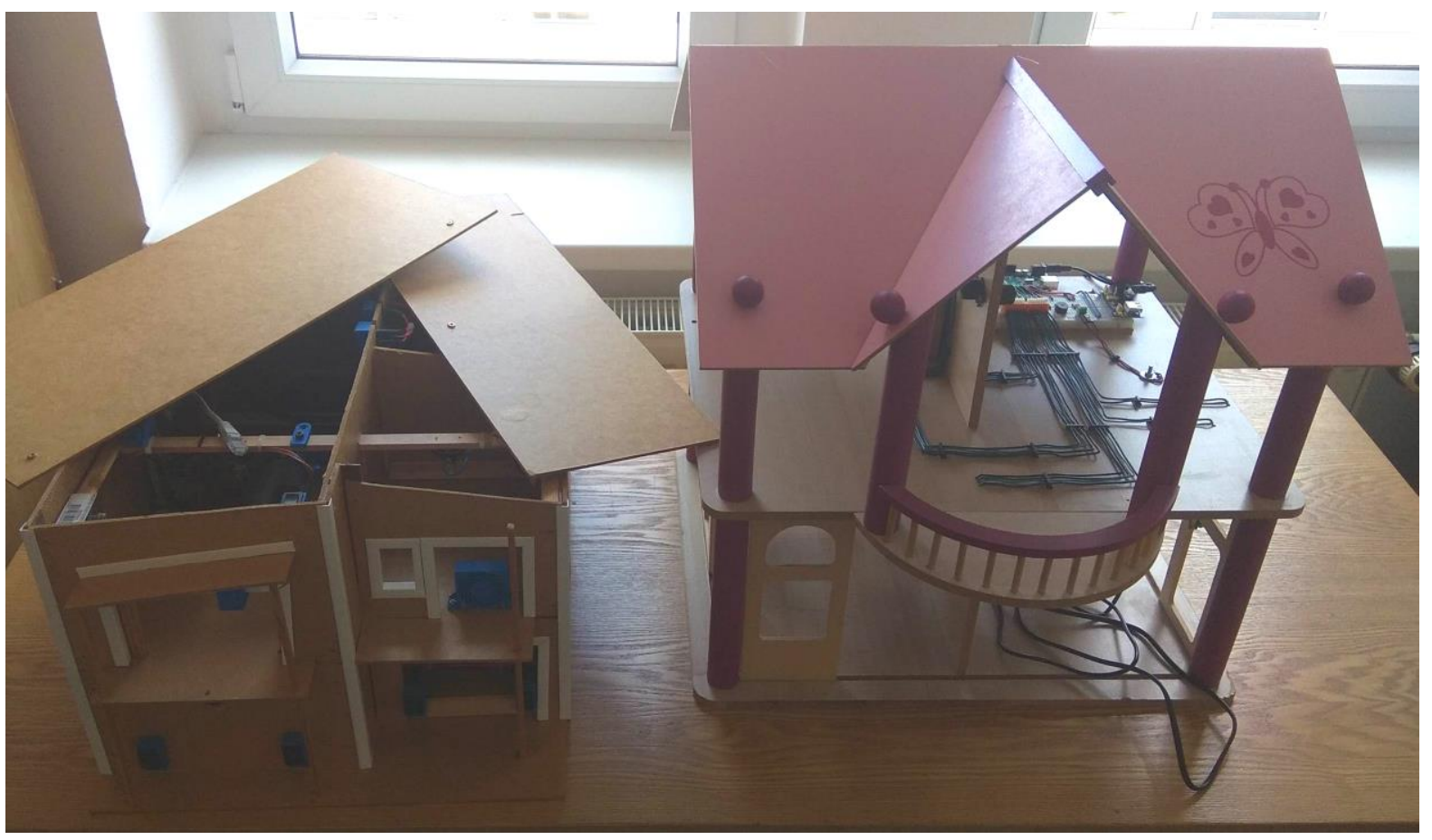

Obrázek 4 - Modelové domy

\subsection{Rídicí systémy a softwarové ovládání inteligentního domu}

U prvního modelového domu se studenti, na základě porovnání stávajících kompletních systémů (Loxone, Jablotron, Siemens), rozhodli pro volbu PLC systému, který umožňuje hybridní zapojení a tedy obsahuje jak sběrnici, tak centrální rídící jednotku (Foxtrot CP-1016).

- Hlavními kritérii při výběru byly např́íklad: 
- Robustnost (Odolnost proti mechanickému poškození, prachu, vlhkosti atd).

- Kompaktnost (Co nejmenší zástavbovou plochu PLC )

- Spolehlivost (Nasazení PLC v nebezpečných provozech)

- Poruchovost (Střední dobu poruchy až 10 mil. hodin )

- Diagnostika (Schopnost autodiagnostiky, nebo signalizace poruchy)

- Možnost konfigurace (Možnost přizpůsobení PLC konkrétní aplikaci (počet vstupů, výstupů, možnost připojení sběrnice, LAN, atd.)

- Servis (Rychlý servis a dostupnost náhradních dílů minimálně 10 let po skončení výroby)

Druhý modelový dům měl hlavní požadavky na co největší možnosti aplikace, a proto se rozhodl pro systém řízený mikropočitačem Arduino Mega2560

U prvního modelového domu byl použit, $v$ závislosti na rídicím systému programovací jazyk ST (strukturovaný text) u druhého pak Wiring.

Zásadním požadavkem na inteligentní domácnost je jeho ovládání softwarovými prostředky. U prvního domu byla vytvořena webová aplikace tzn je možné ovládat jednotlivé prvky domu z jakéhokoli zařízení s internetovým připojením a možností webového rozhraní (Obrázek 5 ).

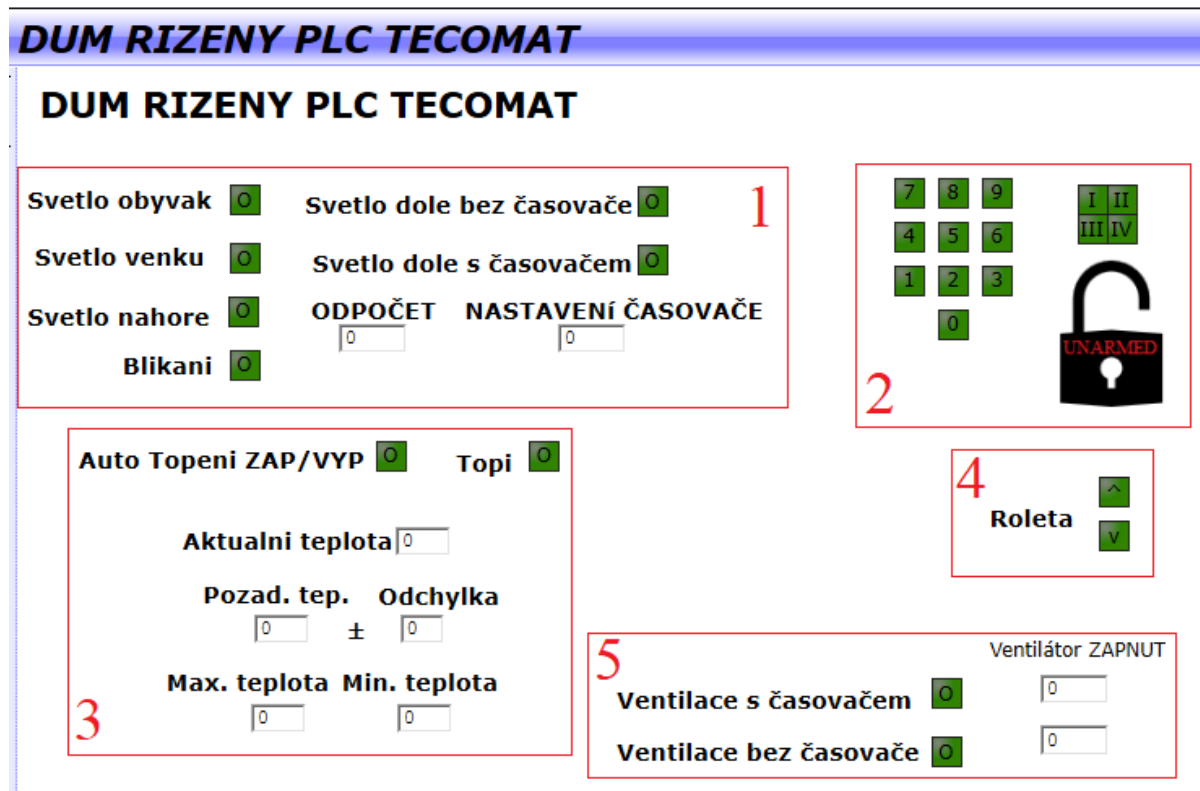

Obrázek 5 - Webová aplikace

$\checkmark$ prípadě druhého domu byla zvolena mobilní aplikace (Blynk) a pro bezpečnostní systém terminál s LED displejem (Obrázek 6). 


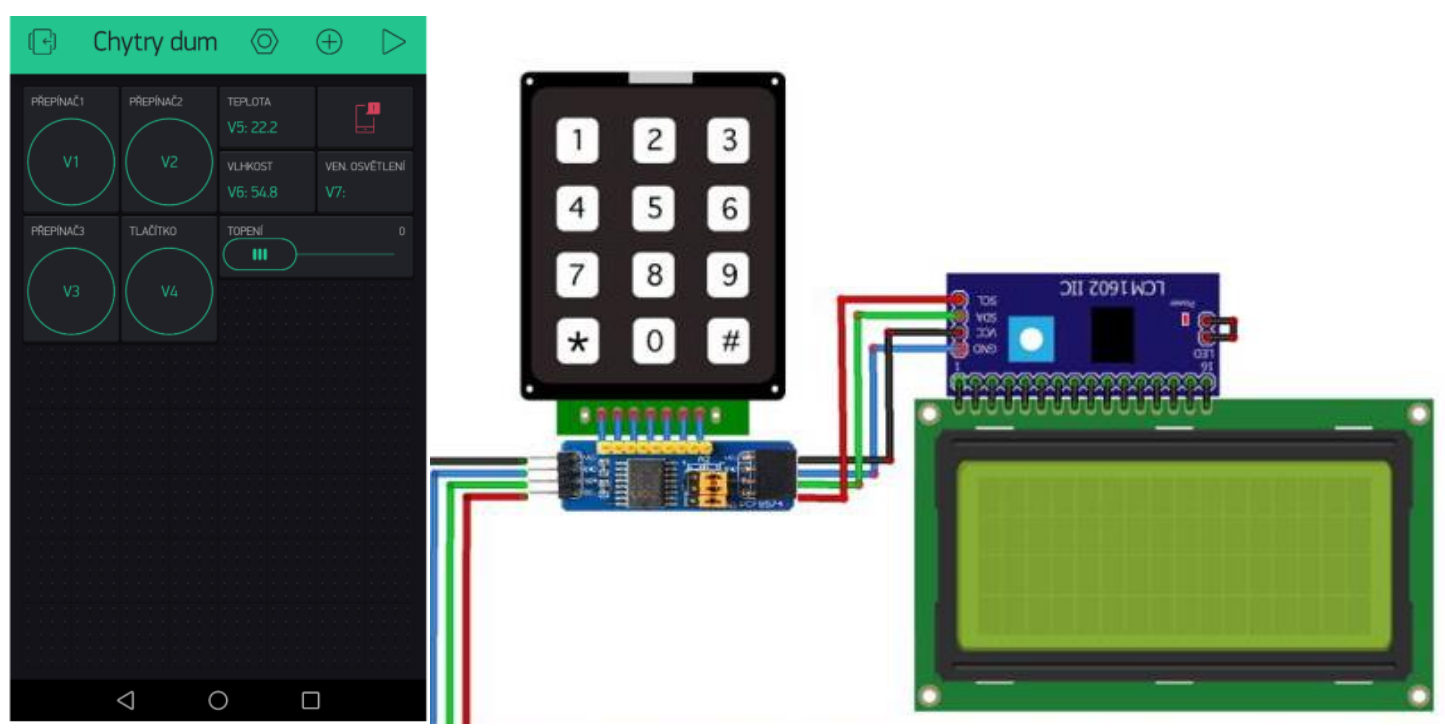

Obrázek 6 - Vzdálené ovládání druhého domu

\subsection{Realizace systémů osvětlení}

U prvního modelového domu bylo realizováno osvětlení $24 \mathrm{~V}$ žárovkou regulované pomocí:

- Tlačítka (první patro) - stiskem libovolného tlačítka (hardwarové nebo softwarové) při zhasnuté žárovce tuto žárovku rozsvítíme. Stlačení kteréhokoliv tlačítka při rozsvícené žárovce znamená její vypnutí

- Přepínače (obývací pokoj) - stejný případ jako nahoře, avšak přepínač zůstává ve zvolené poloze. Osvětlení je realizováno HW přepínačem a SW tlačítkem.

- Tlačítky s časovačem (přízemí) - krátkým stiskem (2xHW a 2xSW) a uvolněním se zapne časovač a světlo svítí po dobu deseti sekund, každým dalším stiskem a uvolněním se $\mathrm{k}$ době svícení přičte dalších deset sekund. Obě HW tlačítka mají stejnou funkci krátkým stiskem a uvolněním se zapne časovač a světlo svítí po dobu deseti sekund, každým dalším stiskem a uvolněním se $\mathrm{k}$ době svícení přičte dalších deset sekund. Pokud je tlačítko podrženo déle než tři vteřiny, tak dojde $\mathrm{k}$ deaktivaci časovače a světlo svítí do té doby, než je stejně dlouhým stiskem tlačítka vypnuto. První SW tlačítko se používá pro zapnutí světla s časovačem, druhé bez časovače.

- Přepínač s časovačem (venkovní osvětlení) - když je žárovka zhasnuta a dojde $\mathrm{k}$ přepnutí jednoho ze dvou hardwarových tlačitek nebo zapnutí softwarového, žárovka se rozsvití. Vypnutí funguje obdobě, avšak po stisku tlačítka (HW nebo SW), se spustí časovač a žárovka svítí, dokud časovač nenabude předvolené hodnoty.

Druhý modelový dům je rízen zejména pomocí inteligentní elektroinstalace (prvky jsou vzájemně propojení sběrnicovým kabelem - Ize je tedy vzájemně ovládat). Veškeré osvětlení je realizováno pomocí LED diod. Model obsahuje 
pouze vnitřní a venkovní osvětlení. Vnitřní osvětlení je ovládáno přepínači, venkovní tlačítkem (viz model č.1).

Oba modely je možno ovládat dálkově viz předchozí kapitola.

\subsection{Realizace systémů vytápění a ventilace}

První systém je možné ovládat pomocí tlačítek a ukazatelů ve webovém rozhraní. Vytápění je realizováno pomocí teplotního čidla POU, zdrojem tepla $\mathrm{v}$ podobě $24 \mathrm{v}$ žárovky umístěné pod čidlem. Po stisknutí tlačítka automatického topení začne žárovka svítit (topí). Dále je zde možné nastavit požadovanou teplotu a teplotní odchylku, s kterou bude POU pracovat. Zobrazovanými údaji jsou aktuální teplota, maximální a minimální teplota, při které topení vypíná, resp. zapíná.

Větrání zajišt'uje ventilátor, který je možné ovládat jak jedním HW tlačítkem, tak dvěma SW vypínači. Stejně jako světlo s tlačítkem a časovačem je i tento ventilátor vybaven časovačem vypnutí.

Jako doplněk pak slouží ovládání rolet. Roleta je připojena na tří polohové tlačítko a dvě SW tlačítka, kterými se ovládá. Stiskem HW nebo SW tlačítka uvedeme roletu do pohybu jedním směrem. Opětovným stiskem stejného HW nebo SW tlačítka se roleta zastaví. K rozpohybování nebo zastavení rolety $\mathrm{v}$ druhém směru dojde stejným způsobem. Pohyb zajišt'uje krokový motor.

\subsection{Bezpečnostní systém}

Oba bezpečnostní systémy jsou realizovány pomocí pohybového PIR čidla. U prvního modelového domu je možné systém ovládat přes webové rozhraní, kde se nalézají tlačítka a ukazatele pro zapnutí a vypnutí alarmu. Alarm funguje standartním způsobem. Při zadání čtyřmístného pinu se aktivuje čidlo, a pokud zaznamená pohyb, uvede se do provozu alarm a osvětlení celého domu začne blikat. $\mathrm{K}$ deaktivaci alarmu dojde opětovným zadáním pin kódu.

Druhý modelový dům má zabudované ovládání, jak již bylo prezentováno na Obrázku 5. Po zapnutí systému (Arduino) je bezpečnostní systém aktivní. $\mathrm{K}$ jeho deaktivaci se tak jako $v$ prvním prípadě využije čtyřmístný PIN kód, jehož zadávání je zobrazeno na LED displeji ve formě skrytých symbolů „ " “.

Reakce domu na narušení bezpečnosti je stejná jako v přechozím príipadě.

Druhý dům má jako zdroj tepla halogenovou žárovku. Na digitální pin 23 je připojen senzor teploty. Eses MOSFET modul plní funkci regulátoru. Na vstup je přiváděn PWM signál z Arduina, kterým je regulováno výstupní napětí, a tím i povrchová teplota žárovky. Hodnotu PWM signálu Ize nastavit otočným potenciometrem. Topení Ize také řídit přes mobilní aplikaci, ta obsahuje virtuální potenciometr. Úkolem rí́dicího systému je reagovat na oba potenciometry tak, aby se navzájem nevyrušovali. Toho je docíleno tak, že se sice načitaji hodnoty $z$ obou potenciometrů, ale pouze jedna $z$ nich je převedena na výstupní PWM signál. A to je hodnota toho potenciometru, na kterém byla jako posledním zaznamenána změna. 


\section{Závěr}

Bez ohledu na to, že zadání pro realizaci chytré domácnosti nebylo specificky určeno, oba projekty vykazují stejné prvky. Oba projekty obsahovali systémy osvětlení vytápění a bezpečnostní systém v různém rozsahu. Jeden projekt se soustředil více na spolehlivost a nastavení logiky systémů (využití PLC), druhý spíše na všestrannost a modifikovatelnost systémů (Arduino). Obě skupiny si osvojili práci s nejen s elektronikou, počínaje senzory a spínači, přes tvorbu softwarové aplikace po konstrukční návrhy a realizaci držáků včetně jejich 3D tisku (Obrázek 7)

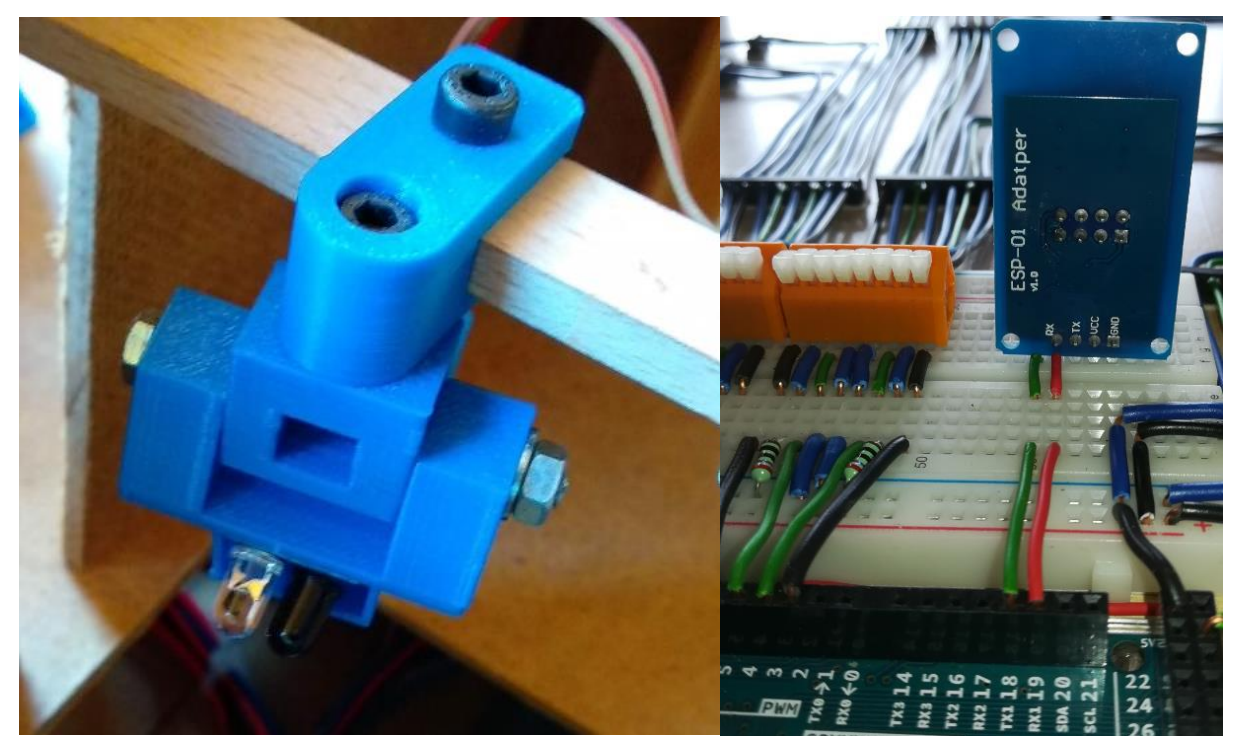

Obrázek 7 - př́klady realizace

Obrovskou výhodou takto vedené projektované výuky je motivace studentů a hloubka získaných znalostí. Nevýhodou jsou pak rozdílné znalosti, které studenti získali (např. práce s PLC či s Arduinem). Proto pro zavedení takového systému se uvažuje o hybridním vzdělávání pro doplnění chybějících znalostí. Hlavní otázkou zůstává, zda tyto znalosti mají studenti nabýt před realizací projektu, aby při rozhodování nalezli odpovědi na základě znalostí, či až po konci projektu, aby byla nejprve rozvíjena kreativita.

\section{Poděkování}

Tento příspěvek byl vytvořen na Technické univerzitě jako součást projektu (21278) - „Optimalizace výrobních systémů, 3D technologií a automatizace“ podpořeného specifickým vysokoškolským výzkumem v rámci studentské grantové soutěže vyhlášené Ministerstvem školství, mládeže a tělovýchovy České republiky v roce 2018.

\section{Použitá literatura}

[1] Blumenfeld, P., et al. Creating usable innovations in systemic reform: Scaling up technology-embedded project-based science in urban schools. Educational psychologist, 2000, vol. 35, no. 3, p. 149-164. ISSN 1532-6985. 
[2] Helle, L., Tznjala, P., Olkinuora, E. Project-based learning in post-secondary education-theory, practice and rubber sling shots. Higher education, 2006, vol. 51, no. 2, p. 287-314. ISSN 0018-1560.

[3] Blumenfeld, P., et al. Motivating project-based learning: Sustaining the doing, supporting the learning. Educational psychologist, 1991, vol. 26, no. 3-4, p. 369-398. ISSN 1532-6985.

[4] Bruffee, K. A. Collaborative learning: Higher education, interdependence, and the authority of knowledge. Baltimore: Johns Hopkins University Press, 1993. ISBN 0-8018-4642-0.

[5] Wurdinger, S., et al. A qualitative study using project-based learning in a mainstream middle school. Improving schools, 2007 , vol. 10, no. 2, p. $150-$ 161. ISSN 13654802.

[6] Wrigley, T. Projects, stories and challenges: more open architectures for school learning. Storyline past, present and future, 2007, p. 166-181.

[7] Mergendoller, J. R., Thomas, J. W. Managing project based learning: Principles from the field [online]. Buck Institute for Education, 2001 [cit. 25. 8. 2019] Dostupné z: http://www.bie.org

[8] Manlig, F., et al. Education Company-An Experience from the Implementation of Problem Based Learning. In: Applied Mechanics and Materials. Trans Tech Publications, 2014, p. 477-482.

[9] Condliffe, B. Project-Based Learning: A Literature Review. Working Paper. MDRC, 2017.

[10] Manlig, F., et al. Educational Company and E-Learning. International Association for Development of the Information Society, 2013.

[11] Wilson, Ch., Hargreaves, T., Hauxwell-Baldwin, R. Smart homes and their users: a systematic analysis and key challenges. Personal and Ubiquitous Computing, 2015, vol. 19, no. 2, p. 463-476.

[12] Garlík, B. Elektrotechnika a inteligentní budovy [online]. Praha, 2014. [cit. 4. 9. 2019]. Dostupné z: https://1url.cz/JMVyl

[13] Vaňuš, J. Systémová technika budov a bytů [online]. 2003 [cit. 4. 9. 2019]. Dostupné z: https://1url.cz/9MVyU

[14] Toman, K. Decentralizované sběrnicové systémy.[online]. Portál pro stavebnictví a technická zařízení budov, 2007 [cit. 4. 9. 2019]. Dostupné z: https://1url.cz/fMVyZ

[15] Inteligentní budovy (2. část): Formulování inteligentní budovy, technologie a struktura řídicích systémů budov [online]. 2012 [cit. 4. 9. 2019]. Dostupné z: https://1url.cz/1MVyC

[16] Bothe, R., Pávek, J. Inteligentní elektroinstalace Nikobus [online]. Verze 1.0. 2004 [cit. 4. 9. 2019]. Dostupné z: https://1url.cz/yMkLn 